\title{
Recording of climate and diagenesis through sedimentary DNA and fossil pigments at Laguna Potrok Aike, Argentina
}

\author{
Aurèle Vuillemin ${ }^{1}$, Daniel Ariztegui ${ }^{2}$, Peter R. Leavitt ${ }^{3,4}$, Lynda Bunting $^{3}$, and the PASADO Science Team* \\ ${ }^{1}$ GFZ German Research Centre for Geosciences, Section 5.3 Geomicrobiology, 14473 Potsdam, Germany \\ ${ }^{2}$ Department of Earth Sciences, University of Geneva, 1205 Geneva, Switzerland \\ ${ }^{3}$ Limnology Laboratory, Department of Biology, University of Regina, Regina, Saskatchewan, S4S 0A2, Canada \\ ${ }^{4}$ Institute of Environmental Change and Society, University of Regina, Regina, Saskatchewan, S4S 0A2, Canada \\ *A full list of authors and their affiliations appears at the end of the paper.
}

Correspondence to: Aurèle Vuillemin (aurele.vuillemin@gfz-potsdam.de)

Received: 12 October 2015 - Published in Biogeosciences Discuss.: 16 November 2015

Revised: 8 April 2016 - Accepted: 14 April 2016 - Published: 27 April 2016

\begin{abstract}
Aquatic sediments record past climatic conditions while providing a wide range of ecological niches for microorganisms. In theory, benthic microbial community composition should depend on environmental features and geochemical conditions of surrounding sediments, as well as ontogeny of the subsurface environment as sediment degraded. In principle, DNA in sediments should be composed of ancient and extant microbial elements persisting at different degrees of preservation, although to date few studies have quantified the relative influence of each factor in regulating final composition of total sedimentary DNA assemblage. Here geomicrobiological and phylogenetic analyses of a Patagonian maar lake were used to indicate that the different sedimentary microbial assemblages derive from specific lacustrine regimes during defined climatic periods. Two climatic intervals (Mid-Holocene, $5 \mathrm{kaBP}$; Last Glacial Maximum, $25 \mathrm{ka} \mathrm{BP}$ ) whose sediments harbored active microbial populations were sampled for a comparative environmental study based on fossil pigments and 16S rRNA gene sequences. The genetic assemblage recovered from the Holocene record revealed a microbial community displaying metabolic complementarities that allowed prolonged degradation of organic matter to methane. The series of Archaea identified throughout the Holocene record indicated an age-related stratification of these populations brought on by environmental selection during early diagenesis. These characteristics were associated with sediments resulting from endorheic lake conditions and stable pelagic regime, high evaporative stress and concomitant high algal productivity. In contrast, sulphate-
\end{abstract}

reducing bacteria and lithotrophic Archaea were predominant in sediments dated from the Last Glacial Maximum, in which pelagic clays alternated with fine volcanic material characteristic of a lake level highstand and freshwater conditions, but reduced water column productivity. Comparison of sedimentary DNA composition with that of fossil pigments suggested that post-depositional diagenesis resulted in a rapid change in the initial nucleic acid composition and overprint of phototrophic communities by heterotrophic assemblages with preserved pigment compositions. Long DNA sequences (1400-900 bp) appeared to derive from intact bacterial cells, whereas short fragments $(290-150 \mathrm{bp})$ reflected extracellular DNA accumulation in ancient sediments. We conclude that sedimentary DNA obtained from lacustrine deposits provides essential genetic information to complement paleoenvironmental indicators and trace post-depositional diagenetic processes over tens of millennia. However, it remains difficult to estimate the time lag between original deposition of lacustrine sediments and establishment of the final composition of the sedimentary DNA assemblage.

\section{Introduction}

Lacustrine sediments represent excellent archives of past environmental conditions (Meyers and Lallier-Vergès, 1999), while providing a wide range of ecological niches for sedimentary microbes resulting in complex composition of sedimentary DNA. Initial climatic conditions influence the flux 
and geochemical make up of organic and inorganic material deposited at the lake bottom (Meyers and Ishiwatari, 1993; Meyers and Teranes, 2001), while microbial activity in the water column (Chen et al., 2008) and after deposition (Freudenthal et al., 2001; Lehmann et al., 2002) further refine the nature of sediments and associated microbial biota. Finally, evolution of sediment environments during early diagenesis is expected to select for the final composition of entombed microbial consortia (Nelson et al., 2007; Zhao et al., 2008).

DNA from ancient sediments has already been successfully employed to study the succession of species as a result of environmental changes in lacustrine settings (Coolen and Gibson, 2009). For example, wet and warm climates result in high bacterial abundance and diversity in the sediment, whereas cold and dry climates favor lower abundance and diversity of microbes (Dong et al., 2010; Vuillemin et al., 2013a). Similarly, changes in terrestrial plant cover along climate-related environmental gradients influence sedimentary microbes via variations in erosion and export of mineral soil and organic matter (OM) to lakes (Clark and Hirsch, 2008). Shifts in lake salinity, as well as modifications of the water column regime, further induce large changes in bacterial populations (Coolen et al., 2006, 2008), while differences in the age and composition (lability) of sedimentary OM can also create distinct bacterial niches (Nelson et al., 2007). Despite the fact that the composition of sedimentary microorganisms shows a strong correspondence to geological and geochemical conditions at the time of deposition in marine environments (Inagaki et al., 2003), little is known about the relative influence of extant environmental conditions and post-depositional sedimentary processes as controls of microbial assemblage composition in deep lacustrine sedimentary settings (Vuillemin et al., 2013b). Moreover, persistent activity of microbes in sediments following burial can further modify geochemical conditions via diagenesis (Inagaki et al., 2006) and alter extant bacterial populations to lead to selective preservation of prior sedimentary assemblages (Miskin et al., 1998; Boere et al., 2011a, b). Therefore, the composition of microbial communities in deep sedimentary environments arises from a combination of climatic conditions at the time of deposition, sediment provenance, diagenetic modifications and metabolic activity and distribution of microbial populations (Ariztegui et al., 2015; Kallmeyer et al., 2015).

This paper tests the hypothesis that the sedimentary DNA assemblage potentially records climatic in-lake processes, sedimentary environments and post-depositional alterations associated with subsurface microbial communities. We compare phylogenetic signatures with pigment data reflecting planktonic production by algae and phototrophic bacteria in an unproductive glacial environment (ca. 25000 years ago) to those characteristic of the productive Holocene (ca. 5000 years ago). Moreover, the detection of in situ microbial activity within sediments from the Holocene and Last Glacial Maximum (LGM) provides a way to assess the per- sistence of sedimentary DNA over time and discriminate nucleic acid sequences of the initial microbial assemblages at the time of deposition (Anderson-Carpenter et al., 2011; Jørgensen et al., 2012) from those arising from diagenetic processes following entombment (Freudenthal et al., 2001).

In this contribution, we take advantage of previous paleoclimatic reconstructions (Gebhardt et al., 2012; Kliem et al., 2013) and blend these results with new pigment data. We also complement geomicrobiological investigations (Vuillemin et al., 2013b, 2014a) with selected phylogenetic data using 16S rRNA gene libraries to focus on discrete horizons in LGM and Holocene. This approach allows us to compare variations in sedimentary DNA over the last 25000 years in response to both past environmental conditions and geochemical evolution of the sediments. Finally, we established six archaeal clone libraries at regular intervals throughout the microbially active sediments of the Holocene period to evaluate the recording of population changes with depth and during diagenesis.

\section{Material and methods}

\subsection{Study site}

Laguna Potrok Aike is a maar lake located in southern Patagonia, Argentina (Fig. 1a) within the Pali Aike volcanic field (Coronato et al., 2013). Due to the persistent influence of Westerly winds in the area (Mayr et al., 2007), the lake is polymictic and, at present, the water column does not exhibit thermal stratification in any season. The basin has a maximum depth of $100 \mathrm{~m}$ (Fig. 1b), while mean annual temperatures range from 4 to $10^{\circ} \mathrm{C}$. The water column is fully oxic $(220 \mu \mathrm{M})$ down to $80 \mathrm{~m}$ depth, where oxygen concentrations rapidly decrease to $60 \mu \mathrm{M}$ in the last $20 \mathrm{~m}$. Conditions are thus oxic but become microoxic at the water-sediment interface (Zolitschka et al., 2006), likely due to the steep morphology of the maar and currents in the profundal zone (Kastner et al., 2010). Oxygen penetration within surface sediment is likely restricted to the first millimeter (Vuillemin et al., 2013a). This hydrologically closed basin contains a sedimentary record of the climatic regime in southernmost South America in which changes in the Westerly winds and ice cap distribution in the Andes regulate variations in regional environmental conditions and in-lake conditions (Fig. 2) such as mixing and hydrological balance (Mayr et al., 2007, 2013; Ohlendorf et al., 2013). During wetter periods, elevated nutrient influx enhances lake primary productivity in the lake (Recasens et al., 2012), as well as colonization of the sediments by microbes (Vuillemin et al., 2013a).

In the framework of the ICDP-PASADO project, a $100 \mathrm{~m}$ long by $7 \mathrm{~cm}$ wide hydraulic piston core (Ohlendorf et al., 2011) was collected and sampled for a detailed geomicrobiological study of the lacustrine subsurface biosphere (Vuillemin et al., 2010). We supplement these insights with 


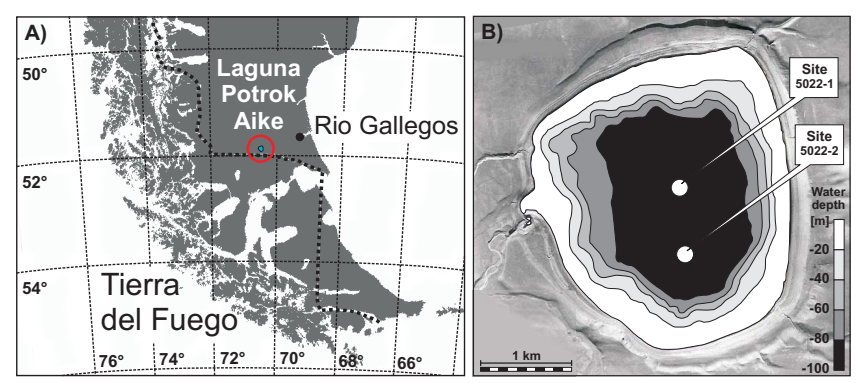

Figure 1. Map of Southern Argentina displaying the location (a) and bathymetric map (b) of Laguna Potrok Aike showing the two drilling sites (Zolitschka et al., 2006). Pore water and geomicrobiological samples were retrieved from cores at site 5022-1, whereas sediments for pigment analysis were obtained from cores at site 5022-2. (a) Holocene

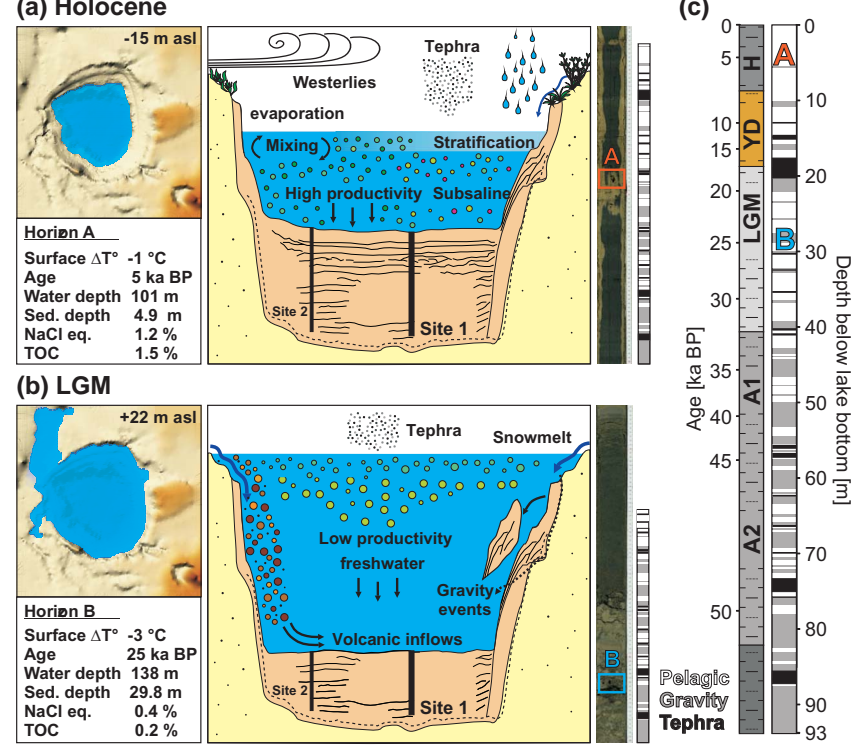

Figure 2. Paleoenvironmental conditions at Laguna Potrok Aike during the Holocene (a) and LGM times (b), with from left to right: climatic and lacustrine parameters, sagittal views of the basin and respective core sections locating the $16 \mathrm{~S}$ rRNA samples. Holocene times correspond with active westerly winds, lake lowstand, subsaline conditions and high primary productivity in the basin and catchment, whereas LGM times are characterized by lake highstand and active overflow, freshwater conditions, low primary productivity in the basin and inflows restricted to runoff from the volcanic catchment. The whole lacustrine sequence (c) is displayed as stratigraphic units in age scale and lithology log in meter scale (after Kliem et al., 2013). The sedimentation can be defined as pelagic (white), gravity (grey) and tephra (black) layers. Time abbreviations stand for Holocene (H), Younger Dryas (YD), Last Glacial Maximum (LGM), Antarctic events 1 (A1) and 2 (A2).

a new 16S rRNA gene analysis of the sedimentary DNA assemblage extracted from the whole Holocene record and one deep ancient LGM horizon (Fig. 2b), as well as a full sequence analysis of key sedimentary carotenoids from eu- karyotic and prokaryotic phototrophs, which preserve well for over 100000 years (Hodgson et al., 2005). Fossil pigment and sedimentary DNA extractions from the two climatic intervals also allow for a unique comparison between climatic and genetic records in the frame of well-established paleoenvironmental reconstructions.

\subsection{Sedimentary features of selected horizons}

Lake basin conditions at the time of the Holocene horizon A (Fig. 2a) were defined as subsaline $(1.2 \% \mathrm{NaCl}$ eq) during a water-column lowstand (Ohlendorf et al., 2013). Annual mean surface atmospheric temperatures were slightly colder than those of the present day $\left(-1^{\circ} \mathrm{C}\right.$; Pollock and Bush, 2013). Sedimentary features of horizon A consist of fine intercalations of laminated silts with soft methane-saturated black clays, reflecting a continuous pelagic to hemipelagic regime (Fig. 2a). In contrast, paleoconditions of the LGM horizon B (Fig. 2b) corresponded with a lake level highstand with freshwater conditions, and colder annual mean surface temperatures $\left(-3^{\circ} \mathrm{C}\right.$; Pollock and Bush, 2013). Sedimentary features of horizon B mainly consist of compacted greyish clays with numerous intercalations of mafic sands associated with terrestrial events (Fig. 2b).

Previous sedimentary studies (Kliem et al., 2013; Gebhardt et al., 2012; Ohlendorf et al., 2013) defined five main lithological units throughout the record of Laguna Potrok Aike. These five units are based on stratigraphic features associated with the frequency of gravity inflows in response to climatic lake level fluctuations (Fig. 2c). Such fluctuations promoted important reworking of the catchment with influx of terrestrial and volcanic detritus to the center of the basin (Zolitschka et al., 2013). Furthermore, time calibration of Laguna Potrok Aike stratigraphy showed that these five lithological units correspond to specific climatic periods, namely the Last Glacial, Antarctic events A2 and A1, LGM, Younger Dryas (YD) and Holocene times (Buylaert et al., 2013; Kliem et al., 2013).

\subsection{On-site sampling and procedures}

Sediment sampling protocols were optimized to avoid potential sources of microbial contamination (Kallmeyer et al., 2006; Vuillemin et al., 2010). The size and configuration of the drilling platform prevented use of an on-site laboratory with sufficient conditions of asepsis, therefore retrieved cores were transported every $90 \mathrm{~min}$ from the platform back to the field laboratory where a detailed protocol was applied to retrieve sediments under the most sterile conditions possible. The aperture of sampling windows allowed a quick retrieval and conditioning of sediments for DNA extraction, 4',6-diamidino-2-phenylindole (DAPI) cell counts, and on-site adenosine- 5 'triphosphate (ATP) assays. Rapid ATP detections were performed on a Uni-Lite NG luminometer (BioTrace) with Aqua-Trace water testers and 
used as an assessment of in situ microbial activity within sediments (Nakamura and Takaya, 2003). Background values measured on micropure $\mathrm{H}_{2} \mathrm{O}$ ranged between 25 and 30 RLU. Thus, a value of 30 was systematically subtracted from the readings for background correction. Pore water was retrieved from small holes drilled in the liners using $0.15 \mu \mathrm{m}$ pores soil moisture samplers (Rhizon Eijkelkamp). All protocols for lithostratigraphic and biogeochemical analyses related to bulk sediment composition, pore water geochemistry and cell count procedures have been published elsewhere (Vuillemin et al., 2013a, b). Complete data sets are available at http://doi.pangaea.de (Vuillemin et al., 2013c, d).

\subsection{Pigment analysis}

All extraction, isolation and quantification followed the standard procedures detailed elsewhere (Leavitt and Hodgson, 2002). In brief, carotenoid, chlorophyll (Chl) and derivative pigments were extracted from 2500 freeze-dried sediment samples into degassed mixtures of organic solvents (i.e. acetone, methanol) and water under an inert $\mathrm{N}_{2}$ atmosphere and filtered through $0.45 \mu \mathrm{m}$ pore membrane filters. Extracts were injected into a Hewlett Packard model 1100 high performance liquid chromatographic (HPLC) system fitted with a reversed-phase C18 column, photo-diode array detector, and fluorescence detector for quantification. Peaks were identified and calibrated using authentic pigment standards (US Environmental Protection Agency and DHI Lab Products, Denmark), unialgal cultures, and reference stocks of sedimentary pigments. Biomarker concentrations (nmol pigment $\mathrm{g}^{-1}$ total organic carbon) were calculated for pigments characteristic of green sulphur bacteria (isorenieratene), total Cyanobacteria represented by the sum of three pigments (echinenone, canthaxanthin, aphanizophyll), purple bacteria (okenone) and mainly diatoms (diatoxanthin). Preservation index was calculated from the ratio of chlorophyll $a$ to its degradation product pheophytin $a$, two pigments indicative of total algal abundance (Leavitt et al., 1993). Shifts in productivity associated with lacustrine conditions were estimated from the ratio of total eukaryotic pigments (alloxanthin, $\beta$-carotene, chlorophyll $a$, chlorophyll $b$, diatoxanthin, fucoxanthin, lutein, phaeophytin $b$, zeaxanthin) to total prokaryotic pigments (canthaxanthin, echinenone, isorenieratene, okenone).

\subsection{Clone library and phylogenetic analysis}

Detailed procedures for DNA extraction, PCR amplification and denaturing gradient gel electrophoresis (DGGE) were published elsewhere (Vuillemin et al., 2013a, 2014b). In brief, total DNA was extracted from sediment samples using the commercial Mobio PowerSoil Isolation kit. Amplifications of the small subunit 16S rRNA gene were performed with the bacterial universal primer pair $27 \mathrm{~F}\left(5^{\prime}\right.$-AGA GTT TGA TCC TGG CTC AG-3') and 1492R (5'-GGT TAC CTT
GTT ACG ACT T-3'). For archaeal gene amplifications, a nested PCR approach was selected to avoid an enrichment step by cultures. The primer pair $4 \mathrm{~F}\left(5^{\prime}\right.$-TCY GGT TGA TCC TGC CRG- $3^{\prime}$ ) and Univ1492R (5'-CGGTTA CCT TGT TAC GAC TT- $3^{\prime}$ ) was used in the first place, followed by the overlapping forward primer $3 \mathrm{~F}\left(5^{\prime}\right.$-TTC CGG TTG ATC CTG CCG GA-3') and reverse primer 9R (5'-CCC GCC AAT TCC TTT AAG TTT C-3'). PCR amplifications resulted in DNA fragments of 1400 and 900 base pairs (bp) for Bacteria and Archaea, respectively. These PCR products were used subsequently to establish clone libraries. For DGGE, a final nested PCR round was performed on both bacterial and archaeal products to fix the GC clam (5' - CGC CCG CCG CGC GCG GCG GGC GGG GCG GGG GCA CGG GGG G -30) and shorten sequences to 150 bp to allow a better denaturation in the gradient gel. Primers 357F-GC (GC clam + 5'-CCT ACG GGA GGC AGC AG-3') with 518R (5'-ATT ACG GCG GCT GCT GG-3') were used for Bacteria and A344F-GC (GC clam + 5' -ACG GGG AGC AGC AGG CGC GA-3') with W31 (5'-TTA CCG CGC TGC TGG CAC-3') for Archaea.

For the cloning procedure, PCR products were purified using the High Pure PCR Product Purification Kit (Roche Diagnostics SA), measured with a Nanodrop ND-1000 Spectrophotometer (Witec AG), and diluted to $10 \mathrm{ng} \mu \mathrm{L}^{-1}$. Two $\mu \mathrm{L}$ of PCR products were ligated to the pCR4-TOPO vector (Invitrogen by life technologies) and cloned into competent Escherichia coli cells. Cloning procedure was performed using the TOPO TA Cloning Kit (Invitrogen by life technologies) following the manufacturer's recommendations. Transformed cells were incubated at $37^{\circ} \mathrm{C}$ for $20 \mathrm{~h}$ on a LB medium containing $1 \mathrm{gL}^{-1} \mathrm{NaCl}, 1 \mathrm{gL}^{-1}$ Bactotryptone, $0.5 \mathrm{~L}^{-1}$ Bactoyeast, $1.5 \mathrm{~g} \mathrm{~L}^{-1}$ Bactoagar and $2 \mathrm{~mL} \mathrm{~L}^{-1}$ ampicillin. To constitute libraries, 86 bacterial clones were selected from samples at 4.97 (43) and 29.77 (40) m sediment depth, and 228 archaeal clones from samples at 0.25 (35), 0.55 (41), 1.90 (42), 2.51 (27), 4.97 (27), 7.81 (21), 9.37 (11), and 29.77 (24) m sediment depth. Sequencing cycles were performed using the BigDye Terminator v.3.1 Cycle Sequencing Kit (Applied BioSystems) with universal primers $27 \mathrm{~F}$ and $1492 \mathrm{R}$ for Bacteria and vector primers D4 and R5 from the BigDye sequencing kit for Archaea. Sequencing was performed on an ABIPRISM $3130 \times 1$ Genetic Analyzer (Applied BioSystems, Hitachi). Sequences were assembled with CodonCode Aligner v.3.7.1 (CodonCode Corporation), aligned on Seaview v.4.3.0 (Gouy et al., 2010) with ClustalW2. Primers were selectively cut off. Chimeras were detected using the online program Bellerophon (Huber et al., 2004). 16S rRNA gene sequences were identified using the megx Geographic-BLAST (http://www.megx.net) and SILVA comprehensive ribosomal RNA databases (Pruesse et al., 2007). The SINA online v.1.2.11 (Pruesse et al., 2012) was used to align, search and classify sequences and their closest matches downloaded from the SILVA database as taxonomic references. All sequences were uploaded on the 
ARB platform (http://www.arb-home.de/) and phylogenetic trees established with the Maximum Likelihood method using the RAxML algorithm with advanced bootstrap refinement of bootstrap tree using 100 replicates (Ludwig et al., 2004). Phylip distance matrices were extracted from phylogenetic trees and exported to the Mothur ${ }^{\circledR}$ v. 1.32.1 software (Schloss et al., 2009) and number of operational taxonomic units (OTUs), rarefaction curves, Chao, Shannon and Dominance-D indices were calculated at $97 \%$ sequence identity cut-off value (Supplement). All our sequences have been deposited in the GenBank database under accession numbers JX272064 to JX272122, JX472282 to JX472399 and KT381303 to KT381433.

To provide a quantitative confirmation of the major elements identified in the clone libraries, a preliminary run of Illumina MiSeq sequencing was performed on the same DNA extracts for horizon A and B. In addition, one surface sample $(0.25 \mathrm{~m}$ depth) was included to provide a reference for the initial microbial assemblages, assuming that it experienced minimal degradation of its DNA following deposition. We used bar code universal primers 515F (5'-GTG CCA GCM GCC GCG GTA A-3') and 806R (5'-GGA CTA CHV GGG TWT CTA AT- $3^{\prime}$ ) to cover 291 bp of the bacterial and archaeal subunit 16S rRNA gene (Supplement).

\section{Results}

\subsection{Geochemical analysis of bulk sediment}

\subsubsection{Organic matter and pore water chemistry}

Total organic carbon (TOC), total nitrogen (TN) and organic phosphorus (OP) displayed very similar stratigraphic variations, with all profiles covarying with grain size and the occurrence of gravity events (Fig. 3, top). Low OM contents were associated with coarse grain sizes and gravity events as they regularly occurred during the Last Glacial period. In contrast, four sediment intervals displayed increased OM values around 70, 40,10 m depth and uppermost sediments (Fig. 3a). In context of the overall stratigraphy (Fig. 3, bottom), these intervals correspond to the Antarctic event A2, early LGM, YD and late Holocene times, respectively.

Chloride concentrations (Supplement) indicated a shift from freshwater $(5.6 \mathrm{mM})$ to subsaline $(16.9 \mathrm{mM})$ conditions during the YD. Nitrite + nitrate concentrations (Supplement) were always very low throughout the sedimentary sequence, with values in between 3.2 and $9.7 \mu \mathrm{M}$. Phosphate concentrations (Fig. 3d) were ca. $105 \mu \mathrm{M}$ in Holocene sediments and most often close to detection limit $(4 \mu \mathrm{M})$ within the rest of the sedimentary sequence. Dissolved iron $\left(\mathrm{Fe}^{2+}\right)$ was often below detection limit $(65 \mu \mathrm{M})$, but was quantifiable from 55 to $15 \mathrm{~m}$ sediment depth, reaching concentrations between 89.5 and $268.6 \mu \mathrm{M}$. The sulphate concentration profile (Fig. 3d) displays frequent variations with baseline values
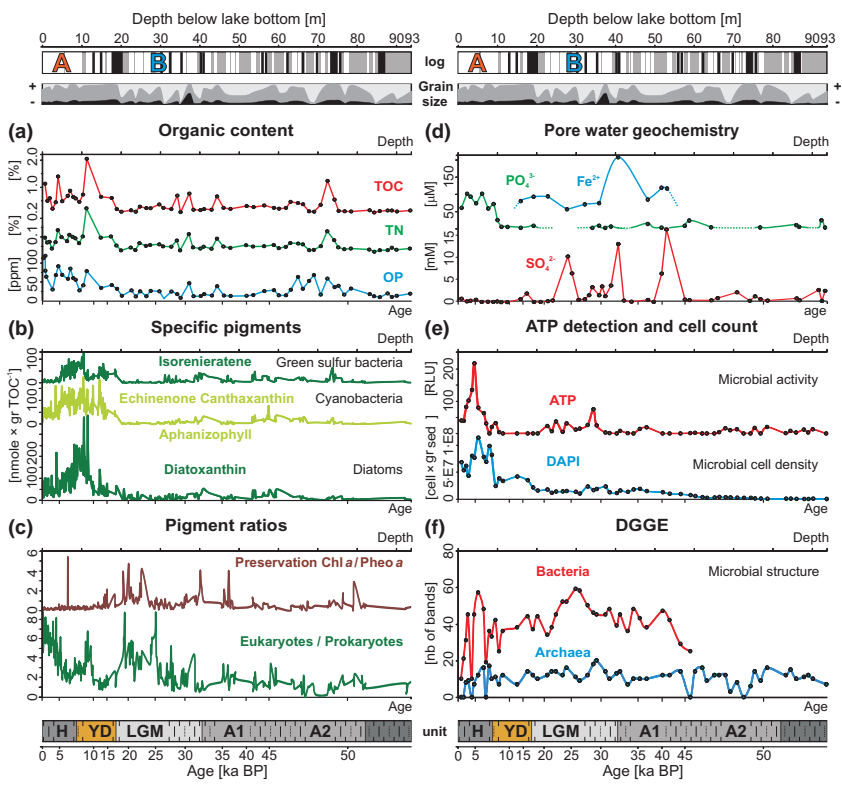

Figure 3. Paleoclimatic and geomicrobiological multiproxy. Top) Stratigraphic sequence of Laguna Potrok Aike, followed by grain size with clay (black), silt (dark grey) and sand (light grey). (a) Total organic carbon (TOC), total nitrogen (TN) and organic phosphorus (OP) from bulk sediment. (b) Specific pigments usually accounting for green sulphur bacteria (isorenieratene), cyanobacteria (echinenone, canthaxanthin, aphanizophyll) and diatoms (diatoxanthin). (c) Preservation index based on the ratio of chlorophyll $a$ to pheophytin $a$, with peaks indicative of increased preservation associated with high sedimentation rates, and ratio of eukaryotic to prokaryotic pigments. (d) Pore water concentrations for phosphate, iron and sulphate. (e) On-site adenosine triphosphate (ATP) detections and 4',6diamidino-2-phenylindole (DAPI) cell counts respectively used as indices of microbial activity and population density. (f) Number of bands from DGGE gels is used as relative index of structural shifts in bacterial and archaeal communities. Bottom) Lithology log displaying the five units established by Kliem et al. (2013) and their corresponding climatic intervals.

oscillating between 52.0 and $728.7 \mu \mathrm{M}$. Extraordinary peaks were located at 49,38 and $25 \mathrm{~m}$ sediment depth, reaching concentrations of ca. 16.6, 13.2 and $10.2 \mathrm{mM}$, respectively, in concomitance with tephra layers.

\subsubsection{Pigment concentrations}

Analyses of bacterial and algal pigment concentrations provided clear indication for algal abundance (i.e. total productivity) being lower and higher during the LGM and Holocene periods, respectively (Fig. 3b). Specifically, elevated fossil concentrations of isorenieratene $\left(100 \mathrm{nmole} \times \mathrm{gr} \mathrm{TOC}^{-1}\right)$ suggested that bacteria related to sulphur metabolism were an important component of the primary producer community during the late YD and early Holocene (Fig. 3b). Sporadic peaks in isorenieratene concentrations were also observed in the glacial record. In contrast, okenone concentra- 
tions (not shown) were always below 20 nmole $\times$ gr TOC $^{-1}$ in Holocene sediments and close to detection limit in the glacial record. Total Cyanobacteria contributed substantially to the labile OM during the YD and Holocene times, but are present only sporadically within the glacial interval. Finally, diatoxanthin showed that diatoms (Fig. 3b) were abundant during the late YD and early Holocene period in agreement with diatom counts (Recasens et al., 2015). The pigment preservation index (Fig. 3c) displayed sporadic peaks correlating coarse grain sizes and increased sedimentation rates, notably during the LGM and YD transition, due to either degradation of chlorophyll $a$ in coarse sediments or external inputs of pheophytin $a$ reworked from the catchment. Analysis of the ratio of eukaryotic (e.g. diatoms, green algae, cryptophyte algae) to prokaryotic (e.g. cyanobacteria, green and purple sulfur bacteria) pigments (Fig. 3c) revealed that the relative importance of eukaryotic algae increased during climatic transitions (late LGM, YD and early Holocene). Otherwise, baseline values oscillated around 2.0, indicating that prokaryotic biomass is considerably less abundant than the eukaryotic one during the glacial period.

\subsection{Microbial characteristics}

\subsubsection{Microbial activity, density and diversity}

Maximal ATP values (> 100) were recorded in the Holocene sediment in between 8 and $4 \mathrm{~m}$ burial depth, indicating ongoing microbial processes. In contrast, only small peaks of ATP (> 50) were observed in LGM sediments (ca. 40 to $20 \mathrm{~m}$ depth), pointing to a sustained but considerably lower level of microbial activity in discrete horizons. Analysis of DAPI cell counts (Fig. 3e) suggested that microbial populations were densest in Holocene sediments (ca. $5 \mathrm{~m}$ core depth), but that total cell abundance decreased gradually from the YD down through LGM sediments, with minimal values in the deepest glacial record. At present, we cannot distinguish between active, inert or dead cells based on DAPI staining. Instead, analyses of DGGE gel features were used to assess microbial community changes. Here, the number of DGGE bands (Fig. 3f) for Bacteria was maximal at 5 and $30 \mathrm{~m}$ depth, which corresponds with the two intervals where microbial populations appeared active based on ATP levels. The Bacteria signal disappeared below $60 \mathrm{~m}$ sediment depth in horizons potentially corresponding with increased gravity events and early reflooding of the maar (Gebhardt et al., 2012; Kliem et al., 2013). Similarly, the Archaea profile displayed a reduced but stable number of DGGE bands along the entire sedimentary record, with maximal values located around 8 and $35 \mathrm{~m}$ depth (Fig. 3f). In general, the DGGE bands represented short sequences $(150 \mathrm{bp}$ ) which could not be used to distinguish between DNA arising from active taxa, intact dead cells and fragmented extracellular DNA (Corinaldesi et al., 2011). Taken together, these various indices provided evidence for the presence of amplifiable DNA related to microbial populations in decline at depth.

Two sedimentary horizons appeared to be preferentially colonized by microbes and were thus selected within the Holocene and LGM records to establish comparative clone libraries. During gel screening, bacterial clones obtained from the Holocene sample all matched the expected size of the targeted DNA fragment $(1400 \mathrm{bp})$, whereas more than $50 \%$ of the clonal sequences isolated from the LGM sample were shorter (800-600 bp), indicating lower DNA quality in aged sediment, were discarded from further analysis (Supplement).

\subsubsection{Bacterial and archaeal clone libraries}

16S rRNA gene sequences from ca. $5 \mathrm{ka}$ old Holocene sediments showed that Atribacteria and Aminicenantes, respectively former candidate divisions OP9 and OP8 (Rinke et al., 2014), were major phyla of the sedimentary microbial assemblage (Fig. 4). Additional representative Bacteria identified from Holocene deposits were affiliated to Acidobacteria (Barns et al., 1999), Clostridia and SProteobacteria partly related to syntropic species (Jackson et al., 1999; Liu et al., 1999, 2011). In contrast, the microbial assemblage from the ca. $25 \mathrm{ka}$ old LGM interval revealed the significant presence of $\delta$ Proteobacteria (Fig. 4) belonging to the SVA0485 candidate division likely involved in sulphate reduction (Bar-Or et al., 2015). Remarkably, one Acidobacteria sequence was affiliated with known iron reducers (Liesack et al., 1994). Other sequences specific to the LGM horizon clustered with Spirochaetes, Elusimicrobia and Latescibacteria, respectively former candidate division Termite Gut Group 1 and WS3 (Herlemann et al., 2009; Rinke et al., 2014; Youssef et al., 2015). Finally, sequences related to Planctomycetes (Glöckner et al., 2003), Chloroflexi, Bacteroidetes and Actinobacteria could not be uniquely associated with either the Holocene or LGM horizon (Figs. 2 and 4), although their respective sequences still formed separate clusters (Figs. 4 and $6)$.

Despite potential cell migration in soft methane-saturated clays, archaeal sequences obtained from the Holocene record provided evidence for an environmental selection of assemblages with depth in the sedimentary profile (Figs. 5 and 6). Main groups successively identified with depth were affiliated with the Marine Group 1 and Lokiarchaeota (i.e. former Marine Benthic Group B) within the first meter, Methanomicrobia and Bathyarchaeota (i.e. former Miscellaneous Crenarchaeotal Group) plus Marine Benthic Group D within the next $4 \mathrm{~m}$ of sediment, and candidate phyla Hadesarchaea (i.e. former South African Gold Mine Group; Baker et al., 2016) and Bathyarchaeota below $5 \mathrm{~m}$ depth (Fig. 6). Methanogen sequences corresponded with depth to Methanolinea, Methanosarcina, Methanoregula and uncultured Methanomicrobiaceace. Finally, Bathyarchaeota sequences were present throughout Holocene sediments form- 




Figure 4. Maximum likelihood phylogenetic tree of bacterial 16S rRNA gene sequences (1400 bp) recovered at 4.97 and $29.77 \mathrm{~m}$ depth from Holocene (orange types) and LGM (blue types) sediments. Atribacteria and Aminicenantes are the main taxa encountered in the Holocene organic-rich pelagic sediments, whereas sulphate reducers are dominant in the LGM horizon composed of intercalated volcanic mafic sands and hemipelagic sediments. Boldface types signify database references with sequence accession numbers in parentheses. 


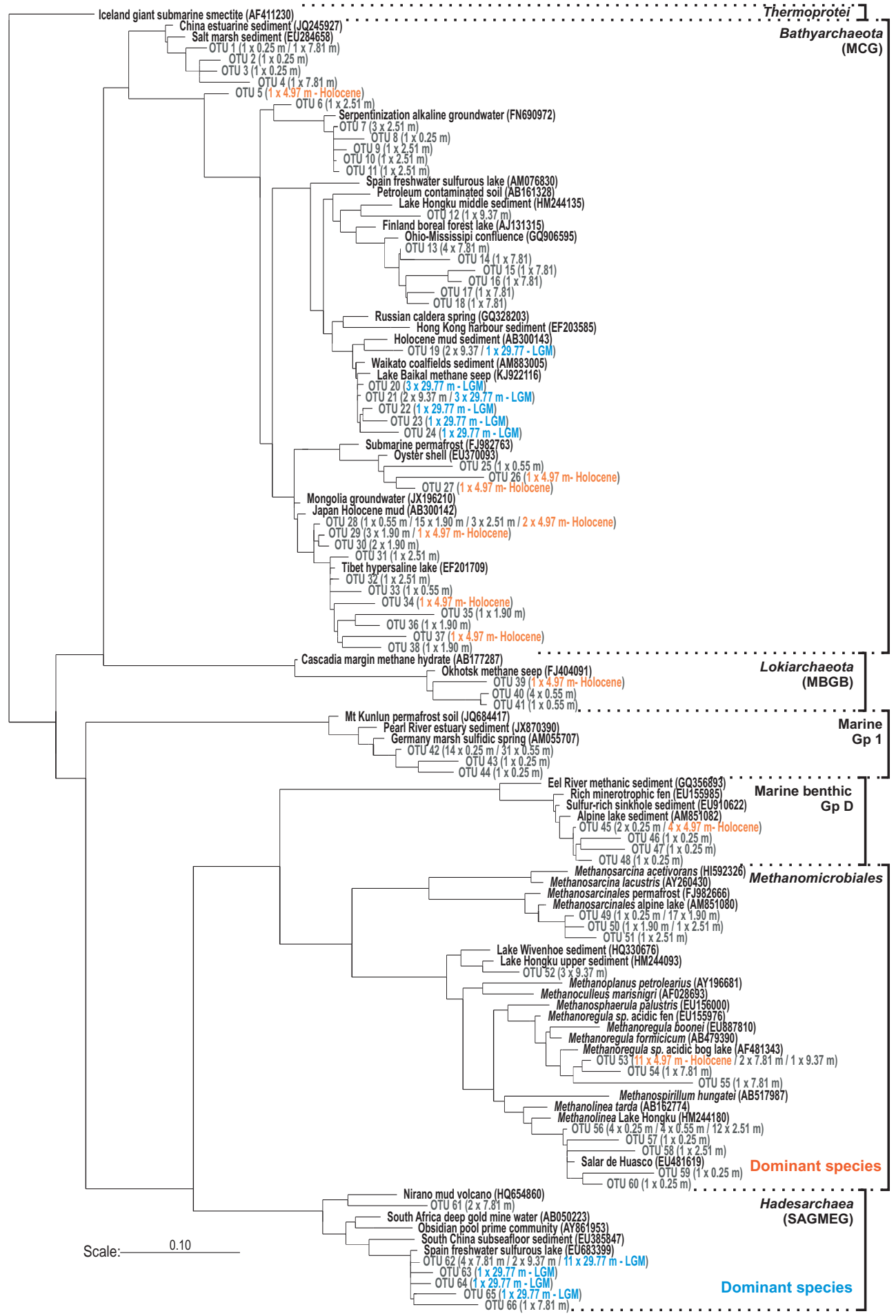

Figure 5. Maximum likelihood phylogenetic tree of archaeal 16S rRNA gene sequences ( $900 \mathrm{bp})$ recovered at $0.25,0.55,1.90,2.51,4.97$, 7.81, 9.37 and $29.77 \mathrm{~m}$ sediment depth. Clone series established throughout the Holocene record (dark grey types) indicate a depth-related evolution of the assemblages, with a general trend from marine groups to methanogens ending with Hadesarchaea (i.e. SAGMEG) sequences. Comparatively, the Holocene archaeal assemblage at $4.97 \mathrm{~m}$ depth (orange types) is mainly composed of Methanomicrobiales and Bathyarchaeota (i.e. MCG), whereas the LGM archaeal assemblage at $29.77 \mathrm{~m}$ depth (blue types) is restricted to Hadesarchaea and Bathyarchaeota divisions. Boldface types signify database references with sequence accession numbers in parentheses. 
ing clusters associated with their respective sampling intervals (Fig. 5). Direct comparison between the LGM and Holocene horizon (Figs. 5 and 6) revealed archaeal assemblages mainly consisting of Methanoregula and Marine Benthic Group D in the Holocene, and mostly Hadesarchaea sequences in the LGM.

High-throughput 16S rRNA sequences supported the main taxa identified in clone libraries, although with different affiliation percentages (Supplement), allowing for general interpretation in terms of sediment populations and related processes. One main taxon (6\%) remained missing in the assemblage of horizon A, specifically the Acetothermia (i.e. former candidate division OP1). In the surface sample, Proteobacteria constituted about $50 \%$ of the assemblage, followed by Planctomycetes, Chloroflexi and Atribacteria. In the surface sample, Proteobacteria constituted about $50 \%$ of the assemblage, followed by Planctomycetes, Chloroflexi and Atribacteria. Checking results for the presence of phototrophs, we noted that sequences related to Cyanobacteria, Chlorobi and chloroplasts were a minority and not uniformly present (Supplement).

\section{Discussion}

\subsection{Holocene and LGM paleoclimatic and geochemical conditions}

The sedimentation regime of Laguna Potrok Aike over the last $51 \mathrm{ka}$ was mainly dependent on climatic variations and river inflows as water level fluctuations led to shore erosion and reworking of the catchment (Kastner et al., 2010; Coronato et al., 2013). Dry conditions during glacial times gave way to regression phases and multiple gravity events, whereas moister conditions promoted transgression phases and pelagic conditions (Haberzettl et al., 2007; Gebhardt et al., 2012; Ohlendorf et al., 2013). During the YD, the position of the Westerlies shifted to lower latitudes and the location of the lake (Kilian and Lamy, 2012; Pollock and Bush, 2013), resulting in elevated wind evaporation and lake level decline along with an overall positive temperature excursion in South Patagonia (Waldmann et al., 2010; Kilian and Lamy, 2012).

In general, the LGM horizon coincides with a period of active hydrology within the lake basin, with both overflow and active inflows into the lake (Haberzettl et al., 2007). Reduced vegetation in the catchment (Haberzettl et al., 2009) promoted periglacial and wind-related erosion (Hein et al., 2010). Tephra layers (Wastegård et al., 2013) with mafic sands reworked from the catchment triggered small-scale shifts in productivity (Hahn et al., 2013) and contributed to punctual increases of iron and sulphate in pore water (Fig. 3d). In contrast, the Holocene horizon corresponds to a period of lake level rise and endorheic phase (Anselmetti et al., 2009; Ohlendorf et al., 2013) with subsaline and
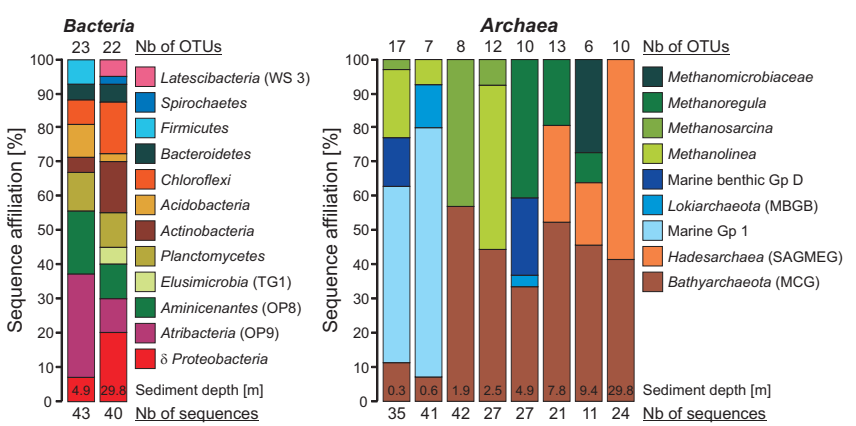

Figure 6. Histograms of identified phylotypes displayed in relative $\%$, with OTU and sequence numbers at the top and bottom, respectively. Left) Several bacterial phylotypes are shared by the Holocene and LGM horizons (i.e. Chloroflexi, Planctomycetes, Bacteroidetes) as they are known ubiquists in aquatic environments. Right) Archaeal phylotypes indicate a gradual evolution with depth of the assemblages. Methanogens correspond in turn to Methanolinea, Methanosarcina and Methanoregula; marine-related sequences to Group 1, Lokiarchaeota and Benthic Group D and disappear below $5 \mathrm{~m}$ depth. Hadesarchaea sequences are only identified from $7.8 \mathrm{~m}$ depth, but dominate the assemblages at $29.8 \mathrm{~m}$ depth.

nitrogen-limiting conditions in the water column (Zhu et al., 2013). Such lake level rise corresponds with important nutrient fluxes, elevated primary productivity (Recasens et al., 2015) and higher microbial colonization of the sediment under pelagic conditions (Vuillemin et al., 2014a).

\subsection{Interpretation of sedimentary DNA}

Overall, microbial populations were defined according to an apparently depth-dependent trend reflecting the receding activity and slow death of microorganisms (Vuillemin et al., 2014a). Subsequent to cell lysis, nucleic acids are released into the surrounding sediment where they can be actively degraded or sorbed to sediments (Corinaldesi et al., 2007, 2011). Exposure of extracellular DNA to microbial processes then results in the turnover or preservation of sequences with depth (Corinaldesi et al., 2008). Theoretically, short fragments are associated mainly with ancient and inactive taxa, whereas longer DNA fragments should better record changes in recent and active taxa. Therefore, clonal 16S rRNA gene sequences (1400 and $900 \mathrm{bp}$ ) are considered significant of some major components of formerly preserved and currently viable microbial assemblages, whereas DGGE bands $(150 \mathrm{bp})$ are likely influenced by the accumulation of extracellular DNA.

Microbial populations were abundant and metabolically active in the sediment of the Holocene period. Archaeal phylotypes indicate a layering of these assemblages with depth likely related to environmental selection during diagenesis. While Bathyarchaeota are major elements of the archaeal assemblage throughout the sediment, predominant methanogens vary with depth from Methanolinea 
to Methanosarcina and Methanoregula. Marine-related sequences also shift from Group 1 to Lokiarchaeota (Spang et al., 2015) and Benthic Group D and are replaced by Hadesarchaea sequences below $5 \mathrm{~m}$ depth. Similar changes in archaeal assemblages have also been identified in marine subseafloor environments (Vigneron et al., 2014). In this latter case, Bathyarchaeota and marine groups are expected to degrade complex organic matter, such as cellulose, proteins and aromatic compounds (Lloyd et al., 2013; Meng et al., 2013). Thus, the present series of Archaea likely reflect an environmental selection of subsurface biosphere during early diagenesis of OM, with an age-related stratification made possible by a stable pelagic regime at that time.

16S rRNA gene sequences provide evidence for the presence of Atribacteria and Aminicenantes (Rinke et al., 2013) as dominant sequences of the assemblage within the organicrich Holocene clays buried at $5 \mathrm{~m}$ depth (ca. $5 \mathrm{ka} \mathrm{BP}$ ) (Fig. 6 and Supplement). These microbes, initially described from hot springs (Hugenholtz et al., 1998), are often abundant in anaerobic marine sediments (Inagaki et al., 2003). Recently, Atribacteria have been described as energy-conservative heterotrophic anaerobes which act either as primary or secondary fermenters (Nobu et al., 2015) capable of syntrophic catabolism (Sieber et al., 2012). Methanoregula (Bräuer et al., 2011) was detected in association with Syntrophus (Jackson et al., 1999) and Syntrophomonadaceae (Liu et al., 2011). GIF9 Chloroflexi, which are closely related to Dehalogenimonas (Moe et al., 2009) and widely abundant in organic-rich anoxic sediments, are presumably homoacetogenic fermenters (Hug et al., 2013). In addition, alkalotolerant species, such as Clostridia (Nakagawa et al., 2006) and Marine Benthic Archaea (Jiang et al., 2008), when active, mainly ferment labile organic compounds (Wüst et al., 2009), whereas cellulose and lignin are degradable by Actinobacteria and Bacteroidetes equally present (Pachiadaki et al., 2011). These assemblages reflect the initial degradation of labile OM from algae and the generation of fermentative byproducts, such as acetate, $\mathrm{H}_{2}$ and $\mathrm{CO}_{2}$, which served as substrates for methane production by Methanomicrobiales. Such substrate evolution during prolonged OM diagenesis promotes the recycling of end products and syntrophic hydrogen consumption, as presently observed with autotrophic methanogenesis and homoacetogenesis (Wüst et al., 2009). Such a pattern also suggests that the final Holocene microbial assemblages arise from metabolic complementarities of component taxa, reinforcing our previous study on their role in the degradation and geochemical cycling of OM (Vuillemin et al., 2014b).

Microbial communities recovered from ca. 25 ka old LGM sediments were not considered dormant or dead, but instead appear to subsist in a viable state at low metabolic rate (Hoelher and Jørgensen, 2013). This LGM assemblage records the intricate presence of organotrophs capable of refractory OM degradation with mostly Atribacteria, Aminicenantes, Elusimicrobia (Herlemann et al., 2009; Febria et al., 2015) and Chloroflexi, to which Acidobacteria (Liesack et al., 1994), Spirochaeta (Hoover et al., 2003), Planctomycetes, Actinobacteria, and Bacteroidetes are added. Syntroph sequences among $\delta$ Proteobacteria and Chloroflexi are consistent with the degradation of secondary metabolites such as propionate (Liu et al., 1999; De Bok et al., 2001; Yamada et al., 2007), while sulphate-reducing $\delta$ Proteobacteria and Hadesarchaea (Takai et al., 2001; Baker et al., 2016) are thought to reflect the specific sediment geochemistry. Finally, Latescibacteria have been recently presented as anaerobes mediating the turnover of multiple complex algal polymers in deep anoxic aquatic habitats (Youssef et al., 2015). This pattern of sequences is interpreted as arising from the intercalation of organic-poor clays with volcanic material that could act as sources of iron and sulphate. In general, conditions at such sedimentary interfaces would greatly limit any methane production (Schubert et al., 2011) and instead select for a microbial assemblage capable of sulphate and iron reduction. $\mathrm{H}_{2} \mathrm{~S}$ production during sulphate reduction likely promotes lithotrophic species via the alteration of mafic minerals (Johnson, 1998; Blanco et al., 2014) and act in the formation of authigenic minerals such as framboidal sulphides (Vuillemin et al., 2013b).

Heterogeneous sedimentation or prolonged exposure to diagenesis can obscure the interpretation of DNA sources. For example, consistent with their ubiquity noted in other studies (Kubo et al., 2012; Farag et al., 2014), Bathyarchaeota and Aminicenantes sequences were not specifically associated with environmental or metabolic features of either the Holocene and LGM horizons, while sequence affiliation to Planctomycetes, Chloroflexi, Actinobacteria and Bacteroidetes appears to be kept constant with depth (Supplement). Indeed, some microorganisms easily tolerate different kinds of environmental change with high functional redundancy (Sunagawa et al., 2015). Global patterns of bacterial distribution in the environment have shown that the main drivers of community composition are temperature and primary production in the oceans (Raes et al., 2011) and salinity and substrate type in sedimentary environments (Lozupone and Knight, 2007). In deep sediment settings, OM anaerobic metabolisms appear as the dominant activities, with cell densities in link to pore-water sulphate concentrations (Orsi et al., 2013) and sedimentation rates (Kallmeyer et al., 2012). All these parameters are consistent with the present microbial assemblages although the Holocene methanogenesis zone overlies the LGM sulphate reduction zone.

Several lines of evidence suggest that patterns of microbial activity and composition did not arise from contamination of ancient sediments with modern microbes. Firstly, phylogenetic results from Holocene and LGM sediments display only one single OTU in common (Fig. 4). Secondly, sedimentary ATP activity recorded less than 2 hours after core recovery shows the same pattern of ATP concentration than that measured substantially later, and is also coherent with more extensive laboratory analyses (Supplement). Thirdly, deep sed- 
iments lacked any of the chemical or lithological characteristics of the younger sediments (Fig. 3), including framboidal iron sulphides, lower salinity, pigment composition, color of clays and absence of gas vugs (Supplement).

\subsection{Sedimentary DNA and fossil pigment preservation}

In addition to diagenesis, important lake level fluctuations can influence the sediment record due to changes in lake morphometry, light penetration and bottom water stratification (Leavitt, 1993; Leavitt and Hodgson, 2002). Complementary analyses of bacterial and algal pigment concentrations indicate high primary productivity during the Holocene while oligotrophic conditions characterized the last glacial period. Sporadically, the pigment preservation index suggests intervals of poor preservation related to low OM content as well as the presence of reworked OM in gravity-related sediments (Hahn et al., 2013). Fortunately, pelagic production can be considered accurately recorded. During the LGM, short intervals of elevated productivity appear to correlate with warming events, tephra inputs and mass movements (Recasens et al., 2015). Still, bacterial sources constitute an important fraction of the organic sedimentary record. During the YD and Holocene, reduced okenone and isorenieratene concentrations indicate two brief periods of stratification associated with lake level lowstands (Zolitschka et al., 2013). Endorheic conditions resulted in nitrate limitation and may have favored Cyanobacteria in comparison to other primary producers (Mayr et al., 2009; Zhu et al., 2013). Reflooding of the maar could explain shifts in planktonic assemblages (Wirth et al., 2013) and increased lake level should have improved conditions for primary production by eukaryotes. However, the water depth difference between the Holocene and LGM times (i.e. $37 \mathrm{~m}$ ) likely promoted OM preservation during lowstand.

Comparison of fossil pigments with sedimentary DNA assemblages suggests that the initial nucleic acid composition of sediments could be rapidly modified by microbial ontogeny following deposition. For example, high concentrations of isorenieratene from brown varieties of green sulfur bacteria (Leavitt et al., 1989; Glaeser and Overmann, 2003) were recorded in the sediments throughout the Holocene, but genetic markers of the relevant carotenoidproducing phototrophic taxa were rare in the mid-Holocene intervals subject to DNA analysis. Similarly, despite high concentrations of cyanobacterial pigments in the Holocene record, related sequences were hardly detected in shallow sediments, even using high-throughput sequencing (Supplement). In this paper, Planctomycetes, Actinobacteria and Bacteroidetes are among the heterotrophs (Fig. 4) which can produce carotenoids pigments (Hahn et al., 2003; Warnecke et al., 2005; Fukunaga et al., 2009; Jehlička et al., 2013) that can be altered to complex derivatives in sedimentary environments (Sinninghe Damsté and Koopmans, 1997; Brocks and Schaeffer, 2008). Of interest is the observation that these heterotrophic taxa are characteristic of anoxic aquatic and sediment habitats and common in ancient algal mat assemblages (De Wever et al., 2005; Schwarz et al., 2007; Song et al., 2012), often persisting long after associated phototrophic bacterial species have been lost (Antibus et al., 2012; Cole et al., 2014; Lage and Bondoso, 2011, 2014). Additionally, initial habitats may play an important role in the preservation of phototrophic sequences. Strong mixing due to Westerly Winds leads to particle resuspension in the water column, while biomats developing on the flanks of the maar and sediment surface can be rapidly buried during gravity events. Our interpretation is that particulate organic matter and planktonic sequences are quickly degraded by heterotrophs during sinking, while early colonization of algal mats after deposition would result in selective recycling of bacteria (Antibus et al., 2012).

\subsection{A model for ancient and extant microbial assemblages}

Taken together, data collected herein and by the complementary studies of the ICDP-PASADO project suggest that climate regulates the influx of organic and inorganic material to the lake basin, which in turn determines water column chemistry, algal productivity and sedimentation of particulate material. Water column conditions (e.g. salinity) and sediment lithology then interact to determine final geochemistry of the sediment. Thus, environmental and geochemical parameters arising from prevailing climatic conditions can exert the initial control on microbial substrates, defining the degree of colonization at the time of deposition (Vuillemin et al., 2013a, 2014a), and subsequently dominant subsurface assemblages brought on by environmental selection during diagenesis. Results presented herein advance this model by characterizing the main elements recorded in the sedimentary DNA and by elucidating the metabolic pathways involved in post-depositional alterations.

During the Holocene interval, elevated rates of OM deposition under pelagic regime led to increased pigment concentrations in the sediment. Sequences potentially derived from ancient assemblages (i.e. Planctomycetes, Actinobacteria and Bacteroidetes) may have emerged from the early degradation of algae and microbial biofilms. Seemingly, these heterotrophic species actively grew at the expense of phototrophic species (Antibus et al., 2012; Cole et al., 2014), leaving intact only their respective pigments although very few sequences of Cyanobacteria and Chlorobi could still be identified in surface sediments (Supplement). Phylogenetic sequences representing the main elements of the subsurface biosphere are characteristic of those exhibiting solely anaerobic heterotrophic metabolism, with Atribacter and Methanomicrobiales as the dominant taxa. They reflect the sediment surrounding geochemical conditions and are indicative of advanced OM degradation during early diagenesis, show- 
ing how long-term persistence and activity of microorganisms can imprint organic proxies (Vuillemin et al., 2014b).

During the LGM period, limited nutrient inputs to the water column and volcanic inflows engendered low primary production mainly by bacteria, presumably in the form of microbial mats reworked to the basin during gravity events. Sequences issued from ancient assemblages seem to refer to complex autotroph-heterotroph interactions (Cole et al., 2014) and likely include Elusimicrobia 4-29 (Herlemann et al., 2009; Febria et al., 2015) and Latescibacteria (Youssef et al., 2015). Surrounding geochemical conditions associated with the formation of OM-poor but iron- and sulphate-rich sediments selected for a subsurface biosphere capable of sulphate reduction and lithotrophy, mainly including sequences affiliated to $\delta$ Proteobacteria and Hadesarchaea (Baker et al., 2016). Related diagenetic processes resulted in the presence of authigenic concretions in LGM sediments (Vuillemin et al., 2013b).

Post-depositional diagenesis plays an important role in modifying the sequences of sedimentary DNA. Long sequences appear to derive from intact bacterial cells, whereas extracellular DNA released upon cell lysis gives way to an accumulation of short fragments in ancient sediments. Analysis of nucleic acid sequences reveals that phototrophic and pre-diagenetic assemblages are rapidly overprinted by subsurface heterotrophic communities. Taxa are then selected according to microbial substrates and geochemical conditions, resulting in the overall decline of microbial activity and density with depth and decreasing turnover of sedimentary DNA. However, despite these insights, further highresolution research is needed to establish the time lag between deposition of the original microbial assemblages and establishment of the final composition of DNA in the sediments.

\section{Conclusions}

Climatic and lacustrine conditions at the time of sediment deposition appeared to be the main factors defining sediment geochemistry and microbial substrates. Preferential preservation of microbial sources already occurred during synsedimentary processes. Sedimentary niches at the time of deposition exerted initial constraints on the development of the subsurface biosphere. After burial, changing geochemical conditions associated with sustained metabolic activity performed a selection of viable microorganisms over time and defined the final microbial assemblages. Genetic information related to phototrophic communities was mostly erased by heterotrophic bacteria while conserving pigment compositions. Identified taxa were in fine characteristic of conditions associated with past environmental and present geochemical factors, with Atribacteria and methanogens, sulphate reducers and Hadesarchaea as dominant species in the Holocene and LGM sediment, respectively.
Further research using a combination of DNA and other proxies will advance our understanding of the mechanisms forming sedimentary nucleic acid assemblages. For example, at present, it is unclear whether microorganisms actively grew for centuries in past sedimentary environments or whether their sequences were merely entombed during the study period, leaving uncertainties concerning the temporal lag between original microbial deposition and establishment of the final composition of sedimentary DNA. Similarly, we also recognize that our analytical platform represent a preliminary insight into genetic variations of Laguna Potrok Aike sediments and that the length of the targeted sequence $(1400 \mathrm{bp})$ likely prevented the detection of partially preserved phototrophic bacteria (<300 bp). However, the rapid development of single cell sequencing technologies and metatranscriptomic analysis will enable a refined view of deep biosphere activities, while massive parallel sequencing will provide extensive phylogeny of microbial DNA in lake deposits.

This study provides new evidence for mechanism underlying the preservation of sedimentary DNA sequences. We show clearly that sedimentary assemblages of nucleic acids differ among major historical climate zones and that some initial elements even sustain activity for 25000 years after burial, albeit at low metabolic rates. Moreover, the present results demonstrate that sedimentary DNA could help reconstructing microbial diagenetic processes undergone by lacustrine sediments and favorably complement paleoreconstructions based on fossil pigments. Application of this approach to other lake sequences will improve interpretation of past climate proxies and eventually disentangle depositional from diagenetic signals.

\section{Team members}

Principal investigators of the PASADO project are: Flavio Anselmetti (Institute of Geological Sciences, Quaternary Geology, University of Bern, 3012 Bern, Switzerland); Daniel Ariztegui (Department of Earth Sciences, University of Geneva, 1205 Geneva, Switzerland); Hugo Corbella (Museo Argentino de Ciencias Naturales Bernardino Rivadavia, C1405 Buenos Aires, Argentina); Pierre Francus (Centre Eau Terre Environnement, Institut National de la Recherche Scientifique, G1K 9A9 Québec, Canada); Andreas Lücke (Forschungszentrum Jülich IBG-3, 52428 Jülich, Germany); Nora I. Maidana (Facultad de Ciencias Exactas y Naturales, University of Buenos Aires, C1428EGA Buenos Aires, Argentina); Christian Ohlendorf (GEOPOLAR, Institute of Geography, University of Bremen, 28359 Bremen, Germany); Frank Schäbitz (Seminar für Geographie und ihre Didaktik, University of Cologne, 50931 Cologne, Germany); Stefan Wastegård (Department of Physical Geography and Quaternary Geology, Stockholm University, 10691 Stockholm, Sweden); Bernd Zolitschka (GEOPOLAR, Insti- 
tute of Geography, University of Bremen, 28359 Bremen, Germany).

\section{Data availabaility}

Present scientific data are archived and publicly available at PANGAEA ${ }^{\circledR}$ Data Publisher for Earth \& Environmental Science and GenBank ${ }^{\circledR}$ National Center for Biotechnology Information genetic sequence database (Vuillemin et al., 2013c, d).

\section{The Supplement related to this article is available online at doi:10.5194/bg-13-2475-2016-supplement.}

Author contributions. Aurèle Vuillemin carried out field sampling, 16S fingerprinting techniques and bulk sediment analyses. Daniel Ariztegui designed the research as principal investigator of the PASADO project and carried out field sampling. Peter R. Leavitt and Lynda Bunting performed pigment extractions and analyses. Aurèle Vuillemin wrote the initial manuscript, and all authors edited and revised the paper.

Acknowledgements. We thank funding support from International Continental Scientific Drilling Program; Swiss National Science Foundation (Grant 200020-119931/2) and University of Geneva (Switzerland); University of Bremen and Deutsche Forschungsgemeinschaft (Germany); the Natural Sciences and Engineering Research Council of Canada; Fulbright Canada; University of Buenos Aires and Secretaría de Ciencia y Tecnología de Córdoba (Argentina); Vetenskapsrädet of Sweden; and the GFZ German Research Centre of Geosciences.

The help during cloning procedures of J. Pawlowski, M. Holzmann, F. Lejzerowicz, L. Perret-Gentil and their research partners at the University of Geneva (Switzerland) is kindly acknowledged. S. Liebner and M. Winkel at the GFZ German Research Centre for Geosciences of Potsdam are acknowledged for their help on the use of ARB. We thank C. Mayr, A. Lücke and S. Becker for sampling and processing pore water analyses.

The article processing charges for this open-access publication were covered by a Research

Centre of the Helmholtz Association.

Edited by: H. Niemann

\section{References}

Anderson-Carpenter, L. L., McLachlan, J. S., Jackson, S. T., Kuch, M., Lumibao, C. Y., and Poinar, H. N.: Ancient DNA from lake sediments: Bridging the gap between paleoecology and genetics, BMC Evol. Biol., 11, 1-15, 2011.
Antibus, D. E., Leff, L. G., Hall, B. L., Baeseman, J. L., and Blackwood, C. B.: Cultivable bacteria from ancient algal mats from the McMurdo Dry Valleys, Antarctica, Extremophiles, 16, 1051014, 2012.

Anselmetti, F., Ariztegui, D., De Batist, M., Gebhardt, C., Haberzettl, T., Niessen, F., Ohlendorf, C., and Zolitschka, B.: Environmental history of southern Patagonia unraveled by the seismic stratigraphy of Laguna Potrok Aike, Sedimentology, 56, 873-892, 2009.

Ariztegui, D., Thomas, C., and Vuillemin, A.: Present and future of subsurface studies in lacustrine sediments through scientific drilling, Int. J. Earth Sci., 104, 1655-1665, 2015.

Baker, B. J., Saw, J. H., Lind, A. E., Lazar, C. S., Hinrichs, K.U., Teske, A. P., and Ettema, T. J. G.: Genomic inference of the metabolism of cosmopolitan subsurface Archaea, Hadesarchaea, Nature Microbiology, 1, 16002, doi:10.1038/nmicrobiol.2016.2, 2016.

Barns, S. M., Takala, S. L., and Kuske, C. R.: Widse distribution of members of the bacterial kingdom Acidobacterium in the environment, Appl. Environ. Microb., 65, 1731-1737, 1999.

Bar-Or, I., Ben-Dov, E., Kushmaro, A., Eckert, W., and Sivan, O.: Methane-related changes in prokaryotes along geochemical profiles in sediments of Lake Kinneret (Israel), Biogeosciences, 12, 2847-2860, doi:10.5194/bg-12-2847-2015, 2015.

Blanco, Y., Rivas, L. A., García-Moyano, A., Aguirre, J., CruzGil, P., Palacin, A., van Heerden, E., and Parro, V.: Deciphering the Prokaryotic Community and Metabolisms in South African Deep-Mine Biofilms through Antibody Microarrays and Graph Theory, PLoS ONE, 9, 1-26, 2014.

Boere, A .C., Damsté, J. S. S., Rijpstra, I. C., Volkman, J. K., and Coolen, M. J. L.: Source-specific variability in post-depositional DNA preservation with potential implications for DNA based paleoecological records, Org. Geochem., 42, 1216-1225, $2011 \mathrm{a}$.

Boere, A. C., Rijpstra, W. I. C., De Lange, G. J., Damste, J. S. S., and Coolen, M. J. L.: Preservation potential of ancient plankton DNA in Pleistocene marine sediments, Geobiology, 9, 377-393, $2011 b$.

Bräuer, S. L., Cadillo-Quiroz, H., Ward, R. J., Yavitt, J. B., and Zinder, S. H.: Methanoregula boonei gen. nov., sp. nov., an acidiphilic methanogen isolated from an acidic peat bog, Int. J. Syst. Evol. Micr., 61, 45-52, 2011.

Brocks, J. J. and Schaeffer, P.: Okenane, a biomarker for purple sulfur (Chromatiaceae), and other new carotenoid derivatives from the $1640 \mathrm{Ma}$ Barney Creek Formation, Geochim. Cosmochim. Ac., 72, 1396-1414, 2008.

Buylaert, J. P., Murray, A. S., Gebhardt, C., Sohbati, R., Ohlendorf, C., Thiel, C., and Zolitschka, B.: Luminescence dating of the PASADO core 5022-1D from Laguna Potrok Aike (Argentina) using IRSL signals from feldspar, Quaternary Sci. Rev., 71, 7080, 2013.

Chen, F., Zhang, L., Yang, Y., and Zhang, D.: Chemical and isotopic alteration of organic matter during early diagenesis : Evidence from the coastal area off-shore the Pearl River estuary, south China, J. Marine Syst., 74, 372-380, 2008.

Clark, I. M. and Hirsch, P. R.: Survival of bacterial DNA and culturable bacteria in archived soils from the Rothamsted Broadbalk experiment, Soil Biol. Biochem., 40, 1090-1102, 2008.

Cole, J. K., Hutchison, J. R., Renslow, R. S., Kim, Y.-M., Chrisler, W. B., Engelmann, H. E., Dohnalkova, A. C., Hu, D., Metz, T. O., 
Fredrickson, J. K., and Lindemann, S. R.: Phototrophic biofilm assembly in microbial-mat-derived unicyanobacterial consortia: model systems for the study of autotroph-heterotroph interactions, Front. Microbiol., 5, 1-18, 2014.

Coolen, M. J. L. and Gibson, J. A. E.: Ancient DNA lake sediment records, PAGES News, 17, 104-106, 2009.

Coolen, M. J. L., Muyzer, G., Schouten, S., Volkman, J. K., and Damsté, J. S. S.: Sulfur and methane cycling during the Holocene in Ace Lake (Antarctica) revealed by lipid and DNA stratigraphy, in: Past and Present Marine Water Column Anoxia, edited by: Neretin, L. N., NATO Science Series: IV-Earth and Environmental Sciences, Springer, Dordrecht, 41-65, 2006.

Coolen, M. J. L., Talbot, H. M., Abbas, B. A., Ward, C., Schouten, S., Volkman, J. K., and Damste, J. S. S.: Sources for sedimentary bacteriohopanepolyols as revealed by $16 \mathrm{~S}$ rDNA stratigraphy, Environ. Microbiol., 10, 1783-1803, 2008.

Corinaldesi, C., Dell'Anno, A., and Danovaro, A.: Early diagenesis and trophic role of extracellular DNA in different benthic ecosystems, Limnol. Oceanogr., 52, 1710-1717, 2007.

Corinaldesi, C., Beolchini, F., and Dell'Anno, A.: Damage and degradation rates of extracellular DNA in marine sediments: Implications for the preservation of gene sequences, Mol. Ecol., 17, 3939-3951, 2008.

Corinaldesi, C., Barucca, M., Luna, G. M., and Dell'Anno, A.: Preservation, origin and genetic imprint of extracellular DNA in permanently anoxic deep-sea sediments, Mol. Ecol., 20, 642654,2011

Coronato, A., Ercolano, B., Corbella, H., and Tiberi, P.: Glacial, fluvial and volcanic landscape evolution in the Laguna Potrok Aike maar area, Southern Patagonia, Argentina, Quaternary Sci. Rev., 71, 13-26, 2013.

De Bok, F. A. M., Stams, A. J. M., Dijkema, C., and Boone, D. R.: Pathway of propionate oxidation by a syntrophic culture of Smithella propionica and Methanospirillum hungatei, Appl. Environ. Microb., 67, 1800-1804, 2001.

De Wever, A., Muylaert, K., Van der Gucht, K., Pirlot, S., Cocquyt, C., Descy, J.-P., Plisnier, P.-D., and Wim Vyverman, W.: Bacterial Community Composition in Lake Tanganyika: Vertical and Horizontal Heterogeneity, Environ. Microbiol., 71, 5029-5037, 2005.

Dong, H., Jiang, H., Yu, B., and Liu, X.: Impacts of environmental changes and human activity on microbial ecosystems on the Tibetan Plateau, NW China, GSA Today, 20, 4-10, 2010.

Farag, I. F., Davis, J. P., Youssef, N. H., and Elshahed, M. S.: Global patterns of abundance, diversity and community structure of the Aminicenantes (candidate phylum OP8), PloS ONE, 9, 1-11, 2014.

Febria, C. M., Hosen, J. D., Crump, B. C., Margaret, A., Palmer, M. A., and Williams, D. D.: Microbial responses to changes in flow status in temporary headwater streams: a cross-system comparison, Front. Microbiol., 6, 1-18, 2015.

Freudenthal, T., Wagner, T., Wenzhöfer, F., Zabel, M., and Wefer, G.: Early diagenesis of organic matter from sediments of the eastern subtropical Atlantic: evidence from stable nitrogen and carbon isotopes, Geochim Cosmochim. Ac., 65, 1795-1808, 2001.

Fukunaga, Y., Kurahashi, M., Sakiyama, Y., Ohuchi, M., Yokota, A., and Harayama, S.: Phycisphaera mikurensis gen. nov., sp. nov., isolated from a marine alga, and proposal of Phycisphaeraceae fam. nov., Phycisphaerales ord. nov. and Phycisphaerae classis nov. in the phylum Planctomycetes, J. Gen. Appl. Microbiol., 55, 267-275, 2009

Gebhardt, A. C., Ohlendorf, C., Niessen, F., De Batist, M., Anselmetti, F. S., Ariztegui, D., Kliem, P., Wastegård, S., and Zolitschka, B.: Seismic evidence of up to $200 \mathrm{~m}$ lake-level change in Southern Patagonia since MIS 4, Sedimentology, 59, 1087-1100, 2012.

Glaeser, J. and Overmann, J.: Characterization and in situ carbon metabolism of phototrophic consortia, Appl. Environ. Microb., 69, 3739-3750, 2003.

Glöckner, F. O., Kube, M., Bauer, M., Teeling, H., Lombardot, T., Ludwig, W., Gade, D., Beck, A., Borzym, K., Heitmann, K., Rabus, R., Schlesner, H., Amann, R., and Reinhardt, R.: Complete genome sequences of the marine planctomycete Pirellula sp. Strain 1, P. Natl. Acad. Sci.-Biol., 100, 8298-8303, 2003.

Gouy, M., Guindon, S., and Gascuel, O.: SeaView version 4: a multiplatform graphical user interface for sequence alignment and phylogenetic tree building, Mol. Biol. Evol., 27, 221-224, 2010.

Haberzettl, T., Mayr, C., Wille, M., and Zolitschka, B.: Linkages between southern hemisphere Westerlies and hydrological changes in semi-arid Patagonia during the last 16,000 years, PAGES News, 15, 22-23, 2007.

Haberzettl, T., Anselmetti, F. S., Bowen, S. W., Fey, M., Mayr, C., Zolitschka, B., Ariztegui, D., Mauz, B., Ohlendorf, C., Kastner, S., Lücke, A., Schäbitz, F., and Wille, M.: Late Pleistocene dust deposition in the Patagonian steppe - extending and refining the paleoenvironmental and tephrochronological record from Laguna Potrok Aike back to 55 ka, Quaternary Sci. Rev., 28, 2927 2939, 2009.

Hahn, A., Kliem, P., Ohlendorf, C., Zolitschka, B., Rosén, P., and the PASADO Science Team: Climate induced changes in the content of carbonaceous and organic matter of sediments from Laguna Potrok Aike (Argentina) during the past $50 \mathrm{ka}$ inferred from infrared spectroscopy, Quaternary Sci. Rev., 71, 154-166, 2013.

Hahn, M. W., Lünsdorf, H., Wu, Q., Schauer, M., Höfle, M. G., Boenigk, J., and Stadler, P.: Isolation of novel ultramicrobacteria classified as Actinobacteria from five freshwater habitats in Europe and Asia, Appl. Environ. Microb., 69, 1442-1451, 2003.

Hein, A. S., Hulton, N. R. J., Dunai, T. J., Sugden, D. E., Kaplan, M. R., and Xu, S.: The chronology of the Last Glacial Maximum and deglacial events in central Argentine Patagonia, Quaternary Sci. Rev., 29, 1212-1227, 2010.

Herlemann, D. P. R., Geissinger, O., Ikeda-Ohtsubo, W., Kunin, V., Sun, H., Lapidus, A., Hugenholtz, P., and Brune A.: Genomic analysis of "Elusimicrobium minutum", the first cultivated representative of the phylum "Elusimicrobia" (formerly Termite Group 1), Appl. Environ. Microb., 75, 2841-2849, 2009.

Hoelher, T. M. and Jørgensen, B. B.: Microbial life under extreme energy limitation, Nat. Rev. Microbiol., 11, 83-94, 2013.

Hodgson, D. A., Vyverman, W., Verleyen, E., Leavitt, P. R., Sabbe, K., Squier, A. H., and Keely, B. J.: Late Pleistocene record of elevated UV radiation in an Antarctic lake, Earth Planet. Sc. Lett., 236, 765-772, 2005.

Hoover, R. B., Pikuta, E. V., Bej, A. K., Marsic, D., Whitman, W. B., Tang, J., and Krader, P.: Spirochaeta americana sp. nov., a new haloalkaliphilic, obligately anaerobic spirochaete isolated from soda Mono Lake in California, Int. J. Syst. Evol. Micr., 53, 815821, 2003. 
Huber, T., Faulkner, G., and Hugenholtz, P.: Bellerophon; a program to detect chimeric sequences in multiple sequence alignments, Bioinformatics, 20, 2317-2319, 2004.

Hug, L. A., Castelle, C. J., Wrighton, K. C., Thomas, B. C., Sharon, I., Frischkorn, K. R., Williams, K. H., Tringe, S. G., and Banfield, J. F.: Community genomic analyses constrain the distribution of metabolic traits across the Chloroflexi phylum and indicate roles in sediment carbon cycling, Microbiome, 1, 1-22, 2013.

Hugenholtz, P., Pitulle, C., Hershberger, K. L., and Pace, N. R.: Novel division level bacterial diversity in a Yellowstone hot spring, J. Bacteriol., 180, 366-376, 1998.

Inagaki, F., Suzuki, M., Takai, K., Oida, H., Sakamoto, T., Aoki, K., Nealson, K. H., and Horikoshi, K.: Microbial communities associated with geological horizons in coastal subseafloor sediments from the Sea of Okhotsk, Appl. Environ. Microb., 69, 7224-7235, 2003.

Inagaki, F., Nunoura, T., Nagakawa, S., Teske, A., Lever, M., Lauer, A., Suzuki, M., Takai, K., Delwiche, M., Colwell, F. S., Nealson, K. H., Horikoshi, K., D’Hondt, S., and Jørgensen, B. B.: Biogeographical distribution and diversity of microbes in methane hydrate-bearing deep marine sediments on the Pacific Ocean Margin, P. Natl. Acad. Sci. USA, 103, 2815-2820, 2006.

Jackson, B. E., Bhupathiraju, V. K., Tanner, R. S., Woese, C. R., and McInerney, M. J.: Syntrophus aciditrophicus sp. nov., a new anaerobic bacterium that degrades fatty acids and benzoate in syntrophic association with hydrogen-using microorganisms, Arch. Microbiol., 171, 107-114, 1999.

Jehlička, J., Osterrothová, K., Oren, A., and Edwards, H. G.: Raman spectrometric discrimination of flexirubin pigments from two genera of Bacteroidetes, FEMS Microbiol. Lett., 348, 97102, 2013.

Jiang, H., Dong, H., Yu, B., Ye, Q., Shen, J., Rowe, H., and Zhang, C.: Dominance of putative marine benthic Archaea in Qinghai Lake, north-western China, Environ. Microbiol., 10, 2355-2367, 2008.

Johnson, D. B.: Biodiversity and ecology of acidophilic microorganisms, FEMS Microbiol. Ecol., 27, 307-317, 1998.

Jørgensen, T., Haile, J., Möller, P., Andreev, A., Boessenkool, S., Rasmussen, M., Kienast, F., Coissac, E., Taberlet, P., Brochmann, C., Bigelow, N. H., Andersen, K., Orlando, L., Gilbert, M. T., and Willerslev, E.: A comparative study of ancient sedimentary DNA, pollen and macrofossils from permafrost sediments of northern Siberia reveals long-term vegetational stability, Mol. Ecol., 21, 1989-2003, 2012.

Kallmeyer, J., Mangelsdorf, K., Cragg, B. A., Parkes, R. J., and Horsfield, B.: Techniques for contamination assessment during drilling for terrestrial subsurface sediments, Geomicrobiol. J., 23, 227-239, 2006.

Kallmeyer, J., Pockalny, R., Adhikari, R. R., Smith, D. C., and D'Hondt, S.: Global distribution of microbial abundance and biomass in subseafloor sediment, P. Natl. Acad. Sci. USA, 109, 16213-16216, 2012.

Kallmeyer, J., Grewe, S., Glombitza, C., and Kitte, J. A.: Microbial abundance in lacustrine sediments: A case study from Lake Van, Turkey, Int. J. Earth Sci., 104, 1667-1677, 2015.

Kastner, S., Ohlendorf, C., Haberzettl, T., Lücke, A., Mayr, C., Maidana, N. I., Schäbitz, F., and Zolitschka, B.: Southern hemispheric westerlies control the spatial distribution of modern sed- iments in Laguna Potrok Aike, Argentina, J. Paleolimnol., 44, 887-902, 2010.

Kilian, R. and Lamy, F.: A review of Glacial and Holocene paleoclimate records from southernmost Patagonia $\left(49-55^{\circ} \mathrm{S}\right)$, Quaternary Sci. Rev., 53, 1-23, 2012.

Kliem, P., Enters, D., Hahn, A., Ohlendorf, C., Lisé-Pronovost, A., St-Onge, G., Wastegård, S., Zolitschka, B., and the PASADO Science Team: Lithology, radiocarbon chronology and sedimentological interpretation of the lacustrine record from Laguna Potrok Aike, southern Patagonia, Quaternary Sci. Rev., 71, 5469, 2013.

Kubo, K., Lloyd, K. G., Biddle, J. F., Amann, R., Teske, A., and Knittel, K.: Archaea of the Miscellaneous Crenarchaeotal Group are abundant, diverse and widespread in marine sediments, ISME J., 6, 1949-1965, 2012.

Lage, O. M. and Bondoso, J.: Planctomycetes diversity associated with macroalgae, FEMS Microbiol. Ecol., 78, 366-375, 2011.

Lage, O. M. and Bondoso, J.: Planctomycetes and macroalgae, a striking association, Front. Microbiol., 5, 1-9, 2014.

Leavitt, P. R.: A review of factors that regulate carotenoid and chlorophyll deposition and fossil pigment abundance, J. Paleolimnol., 9, 109-127, 1993.

Leavitt, P. R. and Hodgson, D. A.: Sedimentary pigments, in: Tracking Environmental Change Using Lake Sediments, edited by: Smol, J. P., Birks, H. J., and Last, W. M., 3, Springer, Dordrecht, 295-325, 2002.

Leavitt, P. R., Carpenter, S. R., and Kitchell, J. F.: Whole-lake experiments: The annual record of fossil pigments and zooplankton, Limnol. Oceanogr., 34, 700-717, 1989.

Lehmann, M. F., Bernasconi, S. M., Barbieri, A., and McKenzie, J. A.: Preservation of organic matter and alteration of its carbon and nitrogen isotope composition during simulated and in situ early sedimentary diagenesis, Geochim. Cosmochim. Ac., 66, 35733584, 2002.

Liesack, W., Bak, F., Kreft, J.-U., and Stackebrandt, E.: Holophaga foetida gen. nov., sp. nov., a new, homoacetogenic bacterium degrading methoxylated aromatic compounds, Arch. Microbiol., 162, 85-90, 1994.

Liu, J., Wu, W., Chen, C., Sun, F., and Chen, Y.: Prokaryotic diversity, composition structure, and phylogenetic analysis of microbial communities in leachate sediment ecosystems, Appl. Microbiol. Biot., 91, 1659-1675, 2011.

Liu, Y., Balkwill, D. L., Aldrich, H. C., Drake, G. R., and Boone, D.: Characterization of the anaerobic propionate-degrading syntrophs Smithella propionica gen. nov., sp. nov. and Syntrophobacter wolinii, Int. J. Syst. Evol. Micr., 49, 545-556, 1999.

Lloyd, K. G., Schreiber, L., Petersen, D. G., Kjeldsen, K. U., Lever, M. A., Steen, A. D., Stepanauskas, R., Richter, M., Kleindienst, S., Lenk, S., Schramm, A., and Jørgensen, B. B.: Predominant archaea in marine sediments degrade detrital proteins, Nature, 496, 215-218, 2013.

Lozupone, C. A. and Knight, R.: Global patterns in bacterial diversity, P. Natl. Acad. Sci. USA, 104, 11436-11440, 2007.

Ludwig, W., Strunk, O., Westram, R., Richter, L., Meier, H., Yadhukumar, Buchner, A., Lai, T., Steppi, S., Jobb, G., Förster, F., Brettske, I., Gerber, S., Ginhart, A. W., Gross, O., Grumann, S., Hermann, S., Jost, R., König, A., Liss, T., Lüssmann, R., May, M., Nonhoff, B., Reichel, B., Strehlow, R., Stamatakis, A., Stuckmann, N., Vilbig, A., Lenke, M., Ludwig, T., Bode, A., 
and Schleiter, K.-H.: ARB: a software environment for sequence data, Nucleic Acids Res., 32, 1363-1371, 2004.

Mayr, C., Wille, M., Haberzettl, T., Fey, M., Janssen, S., Lücke, A., Ohlendorf, C., Oliva, G., Schäbitz, F., Schleser, G. H., and Zolitschka, B.: Holocene variability of the Southern Hemisphere westerlies in Argentinean Patagonia $\left(52^{\circ} \mathrm{S}\right)$, Quaternary Sci. Rev., 26, 579-584, 2007.

Mayr, C., Lücke, A., Maidana, N. I., Wille, M., Haberzettl, T., Corbella, H., Ohlendorf, C., Schäbitz, F., Fey, M., Janssen, S., and Zolitschka, B.: Isotopic fingerprints on lacustrine organic matter from Laguna Potrok Aike (southern Patagonia, Argentina) reflect environmental changes during the last 16,000 years, J. Paleolimnol., 42, 81-102, 2009.

Mayr, C., Lücke, A., Wagner, S., Wissel, H., Ohlendorf, C., Haberzettl, T., Oehlerich, M., Schäbitz, F., Wille, M., Zhu, J., and Zolitschka, B.: Intensified Southern Hemisphere Westerlies regulated atmospheric $\mathrm{CO}_{2}$ during the last deglaciation, Geology, 41, 831-834, 2013.

Meng, J., Xu, J., Qin, D., He, Y., Xiao, X., and Wang, F.: Genetic and functional properties of uncultivated MCG archaea assessed by metagenome and gene expression analyses, ISME J., 8, 650659, 2013

Meyers, P. A. and Ishiwatari, R.: Lacustrine organic geochemistry an overview of indicators of organic matter sources and diagenesis in lake sediments, Org. Geochem., 20, 867-900, 1993.

Meyers, P. A. and Lallier-Vergès, E.: Lacustrine sedimentary organic matter records of Late Quaternary paleoclimates, J. Paleolimnol., 21, 345-372, 1999.

Meyers, P. A. and Teranes, J. L.: Sediment organic matter, in: Tracking Environmental Change Using Lake Sediments, edited by: Last, W. M. and Smol, J. P., Volume 2, Physical and Geochemical Methods, Kluwer Academic Publishers, Dordrecht, 239-270, 2001

Miskin, I., Rhodes, G., Lawlor, K., Saunders, J. R., and Pickup, R. W.: Bacteria in post-glacial freshwater sediments, Microbiology, 144, 2427-2439, 1998.

Moe, W. M., Yan, J., Fernanda Nobre, M., da Costa, M. S., and Rainey, F. A.: Dehalogenimonas lykanthroporepellens gen. nov., sp. nov., a reductively dehalogenating bacterium isolated from chlorinated solvent-contaminated groundwater, Int. J. Syst. Evol. Micr., 59, 2692-2697, 2009.

Nakagawa, S., Inagaki, F., Suzuki, Y., Steinsbu, B. O., Lever, M. A., Takai, K., Engelen, B., Sako, Y., Wheat, C. G., Horikoshi, K., and Integrated Ocean Drilling Program Expedition 301 Scientists: Microbial community in black rust exposed to hot ridge flank crustal fluids, Appl. Environ. Microb., 72, 6789-6799, 2006.

Nakamura, K. and Takaya, C.: Assay of phosphatase activity and ATP biomass in tideland sediments and classification of the intertidal area using chemical values, Mar. Pollut. Bull., 47, 5-9, 2003

Nelson, D. M., Ohene-Adjei, S., Hu, F. S., Cann, I. K. O., and Mackie, R. I.: Bacterial diversity and distribution in the Holocene sediments of a northern temperate lake, Microb. Ecol., 54, 252263, 2007.

Nobu, M. K., Dodsworth, J. A., Murugapiran, S. K., Rinke, C., Gies, E. A., Webster, G., Schwientek, P., Kille, P., Parkes, R. J., Sass, H., Jørgensen, B. B., Weightman, A. J., Liu, W.-T., Hallam, S. J., Tsiamis, G., Woyke, T., and Hedlund, B. P.: Phylogeny and physiology of candidate phylum "Atribacteria" (OP9/JS1) inferred from cultivation-independent genomics, ISME J., 10, 273-286, 2015.

Ohlendorf, C., Gebhardt, C., Hahn, A., Kliem, P., Zolitschka, B., and the PASADO Science Team: The PASADO core processing strategy - A proposed new protocol for sediment core treatment in multidisciplinary lake drilling projects, Sediment. Geol., 239, 104-115, 2011.

Ohlendorf, C., Fey, M., Gebhardt, C., Haberzettl, T., Lücke, A., Mayr, C., Schäbitz, F., Wille, M., and Zolitschka, B.: Mechanisms of lake-level change at Laguna Potrok Aike (Argentina) insights from hydrological balance calculations, Quaternary Sci Rev., 71, 27-45, 2013.

Orsi, W. D., Edgcomb, V. P., Christman, G. D., and Biddle, J. F.: Gene expression in the deep biosphere, Nature, 499, 205-208, 2013.

Pachiadaki, M. G., Kallionaki, A., Dählmann, A., De Lange, G. J., and Kormas, K. A.: Diversity and spatial distribution of prokaryotic communities along a sediment vertical profile of a deep-sea mud volcano, Microb. Ecol., 62, 655-668, 2011.

Pollock, E. W., and Bush, A. B. G.: Atmospheric simulations of southern South America's climate since the last glacial maximum, Quaternary Sci. Rev., 71, 218-228, 2013.

Pruesse, E., Quast, C., Knittel, K., Fuchs, B. M., Ludwig, W., Peplies, J., and Glöckner, F. O.: SILVA: a comprehensive online resource for quality checked and aligned ribosomal RNA sequence data compatible with ARB, Nucleic Acids Res., 35, 7188-7196, 2007.

Pruesse, E., Peplies, J., and Glöckner, F. O.: SINA: accurate high-throughput multiple sequence alignment of ribosomal RNA genes, Bioinformatics, 28, 1823-1829, 2012.

Raes, J., Letunic, I., Yamada, T., Jensen, L. J., and Bork, P.: Toward molecular trait-based ecology through integration of biogeochemical, geographical and metagenomic data, Mol. Syst. Biol., 7, 1-9, 2011.

Recasens, C., Ariztegui, D., Gebhardt, C., Gogorza, C., Haberzettl, T., Hahn, A., Kliem, P., Lisé-Pronovost, A., Lücke, A., Maidana, N. I., Mayr, C., Ohlendorf, C., Schäbitz, F., St-Onge, G., Wille, M., Zolitschka, B., and the PASADO Science Team: New insights into paleoenvironmental changes in Laguna Potrok Aike, Southern Patagonia, since the Late Pleistocene: the PASADO multiproxy record, Holocene, 22, 1323-1335, 2012.

Recasens, C., Ariztegui, A., Maidana, N. I., and Zolitschka, B.: Diatoms as indicators of hydrological and climatic changes in Laguna Potrok Aike (Patagonia) since the Late Pleistocene, Palaeogeogr. Palaeocl., 417, 309-319, 2015.

Rinke, C., Schwientek, P., Sczyrba, A., Ivanova, N. N., Anderson, I. J., Cheng, J. F., Darling, A., Malfatti, S., Swan, B. K., Gies, E. A., Dodsworth, J. A., Hedlund, B. P., Tsiamis, G., Sievert, S. M., Liu, W. T., Eisen, J. A., Hallam, S. J., Kyrpides, N. C., Stepanauskas, R., Rubin, E. M., Hugenholtz, P., and Woyke, T.: Insights into the phylogeny and coding potential of microbial dark matter, Nature, 499, 431-437, 2014.

Schloss, P. D., Westcott, S. L., Ryabin, T., Hall, J. R., Hartmann, M., Hollister, E. B., Lesniewski, R. A., Oakley, B. B., Parks, D. H., Robinson, C. J., Sahl, J. W., Stres, B., Thallinger, G. G., Van Horn, D. J., and Weber, C. F.: Introducing mother: Open-source, platform-independent, community-supported software for describing and comparing microbial communities, Appl. Environ. Microb., 75, 7537-7541, 2009. 
Schubert, C. J., Vazquez, F., Lösekann-Behrens, T., Knittel, K., Tonolla, M., and Boetius, A.: Evidence for anaerobic oxidation of methane in sediments of a freshwater system (Lago di Cadagno), FEMS Microbiol. Ecol., 76, 26-38, 2011.

Schwarz, J. I. K., Eckert, W., and Conrad, R.: Community structure of Archaea and Bacteria in a profundal lake sediment Lake Kinneret (Israel), Syst. Appl. Microbiol., 30, 239-254, 2007.

Spang, A., Saw, J. H., Jørgensen, S. L., Zaremba-Niedzwiedzka, K., Martijn, J., Lind, A. E., van Eijk, R., Schleper, C., Guy, L., and Ettema, T. J. G.: Complex archaea that bridge the gap between prokaryotes and eukaryotes, Nature, 521, 173-179, 2015.

Sieber, J. R., McInerney, M. J., and Gunsalus, R. P.: Genomic insights into syntrophy: The paradigm for anaerobic metabolic cooperation, Annu. Rev. Microbiol., 66, 429-452, 2012.

Sinninghe Damsté, J. S. and Koopmans, M. P.: The fate of carotenoids in sediments: An overview, Pure Appl. Chem., 69, 2067-2074, 1997.

Song, H., Li, Z., Du, B., Wang, G., and Ding, Y.: Bacterial communities in sediments of the shallow Lake Dongping in China, J. Appl. Microbiol., 112, 79-89, 2012.

Sunagawa, S., Coelho, L. P., Chaffron, S., Kultima, J. R., Labadie, K., Salazar, G., Djahanschiri, B., Zeller, G., Mende, D. R., Alberti, A., Cornejo-Castillo, F. M., Costea, P. I., Cruaud, C., d'Ovidio, F., Engelen, S., Ferrera, I., Gasol, J. M., Guidi, L., Hildebrand, F., Kokoszka, F., Lepoivre, C., Lima-Mendez, G., Poulain, J., Poulos, B. T., Royo-Llonch, M., Sarmento, H., Vieira-Silva, S., Dimier, C., Picheral, M., Searson, S., KandelsLewis, S., Bowler, C., de Vargas, C., Gorsky, G., Grimsley, N., Hingamp, P., Iudicone, D., Jaillon, O., Not, F., Ogata, H., Pesant, S., Speich, S., Stemmann, L., Sullivan, M. B., Weissenbach, J., Wincker, P., Karsenti, E., Raes, J., Acinas, S. G., and Bork, P.: Structure and function of the global ocean microbiome, Science, 348, 12613591-12613599, 2015.

Takai, K., Moser, D. P., DeFlaun, M., Onstott, T. C., and Fredrickson, J. K.: Archaeal diversity in waters from deep South African gold mines, Appl. Environ. Microb., 67, 5750-5760, 2001.

Vigneron, A., Cruaud, P., Roussel, E. G., Pignet, P., Caprais, J.-C., Callac, N., Ciobanu, M.-C., Godfroy, A., Cragg, B. A., Parkes, J. R., Van Nostrand, J. D., He, Z., Zhou, J., and Toffin, L.: Phylogenetic and functional diversity of microbial communities associated with subsurface sediments of the Sonora Margin, Guaymas Basin, PLoS ONE, 9, doi:10.1371/journal.pone.0104427, 2014.

Vuillemin, A., Ariztegui, D., Vasconcelos, C., and the PASADO Scientific Drilling Party: Establishing Sampling Procedures in Lake Cores for Subsurface Biosphere Studies: Assessing In Situ Microbial Activity, Sci. Dril., 10, 35-39, doi:10.2204/iodp.sd.10.04.2010, 2010.

Vuillemin, A., Ariztegui, D., and the PASADO Science Team: Geomicrobiological investigations in subsaline maar lake sediments over the last 1500 years, Quaternary Sci. Rev., 71, 119-130, 2013a.

Vuillemin, A., Ariztegui, D., De Coninck, A. S., Lücke, A., Mayr, C., Schubert, C. J., and the PASADO Science Team: Origin and significance of diagenetic concretions in sediments of Laguna Potrok Aike, southern Patagonia, J. Paleolimnol., 50, 275-291, $2013 b$.

Vuillemin, A., Ariztegui, D., De Coninck, A. S., Lücke, A., Mayr, C., Schubert, C. J., and PASADO Science Team: Bulk sediment characteristics and geomicrobiology of sediment core 5022-1J from Laguna Potrok Aike, southern Patagonia, doi:10.1594/PANGAEA.811524, 2013c.

Vuillemin, A., Ariztegui, D., Mayr, C., and Lücke, A.: Geomicrobiology, bulk sediment characteristics and pore water chemistry of sediment cores from Laguna Potrok Aike, southern Patagonia, Dataset \#811524, doi:10.1594/PANGAEA.811523, 2013d.

Vuillemin, A., Ariztegui, D., Lücke, A., Mayr, C., and the PASADO Science Team: Paleoenvironmental conditions define current sustainability of microbial populations in Laguna Potrok Aike sediments, Argentina, Aquat. Sci., 76, 101-114, 2014a.

Vuillemin, A., Ariztegui, D., Nobbe, G., Schubert, C. J., and the PASADO Science Team: Influence of methanogenic populations in Holocene lacustrine sediments revealed by clone libraries and fatty acid biogeochemistry, Geomicrobiol. J., 31, 285-298, 2014b.

Waldmann, N., Ariztegui, D., Anselmetti, F. S., Austin Jr., J. A., Moy, C. M., Stern, C., Recasens, C., and Dunbar, R. B.: Holocene climatic fluctuations and positioning of the Southern Hemisphere Westerlies in Tierra del Fuego (54 S), Patagonia, J. Quaternary Sci., 25, 1063-1075, 2010.

Warnecke, F., Sommaruga, R., Sekar, R., Hofer, J. S., and Pernthaler, J.: Abundances, identity, and growth state of Actinobacteria in mountain lakes of different UV transparency, Appl. Environ. Microb., 71, 5551-5559, 2005.

Wastegård, S., Veres, D., Kliem, P., Hahn, A., Ohlendorf, C., Zolitschka, B., and the PASADO Science Team: Towards a late Quaternary tephrochronological framework for the southernmost part of South America the Laguna Potrok Aike tephra record, Quaternary Sci. Rev., 71, 81-90, 2013.

Wirth, S. B., Gilli, A., Niemann, H., Dahl, T. W., Ravasi, D., Sax, N., Hamann, Y., Peduzzi, R., Peduzzi, S., Tonolla, M., Lehmann, M. F., and Anselmetti, F.: Combining sedimentological, trace metal (Mn, Mo) and molecular evidence for reconstructing past water-column redox conditions: The example of meromictic Lake Cadagno (Swiss Alps), Geochim. Cosmochim. Ac., 120, 220-238, 2013.

Wüst, P. K., Horn, M. A., and Drake, H. L.: Trophic links between fermenters and methanogens in a moderatly acidic fen soil, Environ. Microbiol., 11, 1395-1409, 2009.

Yamada, T. Imachi, H., Ohashi, A., Harada, H., Hanada, S., Kamagata, Y., and Sekiguchi, Y.: Bellilinea caldifistulae gen. nov., sp. nov. and Longilinea arvoryzae gen. nov., sp. nov., strictly anaerobic, filamentous bacteria of the phylum Chloroflexi isolated from methanogenic propionate-degrading consortia, Int. J. Syst. Evol. Microbiol., 57, 2299-2306, 2007.

Youssef, N. H., Farag, I. F., Rinke, C., Hallam, S. J., Woyke, T., and Elshahed, M. S.: In silico analysis of the metabolic potential and niche specialization of candidate phylum "Latescibacteria" (WS3), PloS ONE, 10, 1-21, 2015.

Zhao, X., Yang, L., Yu, Z., Peng, N., Xiao, L., Yin, D., and Qin, B.: Characterization of depth-related microbial communities in lake sediment by denaturing gradient gel electrophoresis of amplified 16S rRNA fragments, J. Environ. Sci., 20, 224-230, 2008.

Zhu, J., Lücke, A., Wissel, H., Müller, D., Mayr, C., Ohlendorf, C., Zolitschka, B., and The PASADO Science Team: The last Glacial-Interglacial transition in Patagonia, Argentina: The stable isotope record of bulk sedimentary organic matter from Laguna Potrok Aike, Quaternary Sci. Rev., 71, 205-218, 2013. 
Zolitschka, B., Schäbitz, F., Lücke, A., Corbella, H., Ercolano, B., Fey, M., Haberzettl, T., Janssen, S., Maidana, N., Mayr, C., Ohlendorf, C., Oliva, G., Paez, M. M., Schleser, G. H., Soto, J., Tiberi, P., and Wille, M.: Crater lakes of the Pali Aike Volcanic Field as key sites for paleoclimatic and paleoecological reconstructions in southern Patagonia, Argentina, J. S. Am. Earth Sci., 21, 294-309, 2006.
Zolitschka, B., Anselmetti, F., Ariztegui, D., Corbella, H., Francus, P., Lücke, A., Maidana, N. I., Ohlendorf, C., Schäbitz, F., and Wastegård, S.: Environment and climate of the last 51,000 years - new insights from the Potrok Aike maar lake Sediment Archive prOject (PASADO), Quaternary Sci. Rev., 71, 1-12, 2013. 